Received: 03.06.2014.

Original scientific work

UDK: 316.623/4-053.4:311.212

\title{
CONSTRUCTION OF THE SCALES FOR ESTIMATION OF UNDESIRABLE BEHAVIORS AND SOCIAL SKILLS IN PRESCHOOL CHILDREN
}

Joško Sindik, PhD, Institute for Anthropological Research, Zagreb; josko.sindik@inantro.hr Jelena Šarac, Institute for Anthropological Research, Zagreb

Zvjezdana Sindik, Kindergarten Maslačak, Zaprešić

\section{SUMMARY}

Undesirable behaviors are obstacles for the physical development of a child and for other children in kindergarten, while desirable social skills contribute to the constructive resolution of conflicts among children and to prosocial behaviors. The objectives of the study were: to construct estimation scales of social skills and undesirable behaviors of children; to determine the age and gender differences in the dimensions of both newly constructed measuring instruments; to determine the correlation between the dimensions of the undesirable behaviors of children and their prosocial skills. Teachers assessed the list of characteristics for 597 boys and girls of preschool age. We constructed two measuring instrument with very satisfactory psychometric properties for the assessment of prosocial behaviors of preschool children, as well as to assess children's socially undesirable behaviors. It was shown that the behaviors that describe the passive social skills are more frequent in girls, while boys more often manifest reactive undesirable behaviors. Older children more often show active social skills and instrumental undesirable behaviors, while they less frequently exhibit reactive undesirable behaviors.

Key words: undesirable behavior, prosocial skills, preschool children,

\section{INTRODUCTION}

Cooperation, empathy and altruism are key features in humans, which separate us from the rest of the animal kingdom (Fehr \& Fishbascher, 2003; Ulutas \& Aksoy, 2009). Such prosocial behaviors, directed to the well-being of the other, are often regarded as the basis of human interaction (Eisenberg \& Fabes, 1998). It has also been suggested that children with better prosocial skills are better adapted to their environment and have better relationships with their peers (Clar \& Ladd, 2000; Ulutas \& Aksoy, 2009). The intention of helping can be motivated by different reasons: from the intrinsic ones to the external motives, such as a reward. Already at the end of their first year, children react emotionally to other people's trouble and in their second year they try to give comfort, help and share the objects they possess with the others. Studies have shown that the rate of prosocial behavior also raises with age in childhood, however in a different pace according to the specific type of behavior. Most studies did not observe sex differences in prosocial behavior and only few showed more accentuated prosocial behavior in girls (Krebs, 1970). However, this could be influenced by a general tendency to characterize girls as the more prosocial gender.

Numerous studies have tried to associate the individual differences in prosocial behavior of children with environmental factors, mostly with the parental and peer influence (in kindergartens and schools) and with media (Eisenberg \& Fabes, 1998; Calvert \& Kotler, 2003; Cole et al., 2003; Ostrov et al., 2006). Research of the genetic influence on the development of prosocial behavior have also been conducted, mostly on mono- and dizygotic twins. Most of the 
studies suggested a moderate influence of the genetic component and shared background in adult twins, but the studies conducted in children showed a higher degree of correlation with the genetics and shared environment (McGue et al., 1993; Lemery \& Goldsmith, 2002; Knafo \& Plomin, 2006). It is known that the influence of shared environment on cognitive abilities decreases with age (McGue et al., 1993; Plomin et al. 2001) and it is therefore assumed that this influence is the strongest in childhood, dropping significantly in adulthood. This has also been confirmed in most of the studies, along with the increased impact of hereditable features with age (Plomin et al. 2001; Knafo \& Plomin, 2006).

Social incompetence of children is a common problem in preschool institutions and it is most often expressed as aggression towards other children. Žužul (1989, in Vlahović-Štetić, 1994) defines aggressive behavior as any physical or verbal reaction which the intention of harming someone in some way, even if not brought to completion. Many studies have suggested that aggressiveness is a stabile trait, which forms itself early in childhood. Instrumental aggression has been detected already in 12-month-old children (Vlahović-Štetić, 1994; Essau \& Conrad, 2006), while intentional aggressive behavior start to emerge between 20th and 23rd month (Scahffer, 1988). The most common form of instrumental aggression occurs at the age of four and it is motivated by a will to possess all toys. At the age of six, most common aggression form is hostile aggression, directed towards the other person (Žužul, 1989, in Vlahović - Štetić, 1994). Development of aggression in children is in high correlation with the development of their prosocial skills - the ones with more prosocial skills tend to be less aggressive (Keresteš, 2002). Different types of aggressive behavior emerge in children depending on their age and sex. Instrumental and physical aggressiveness is more common in younger children, while verbal and hostile aggressiveness are characteristic for the school children (Žužul, 1980, in Marangunić, 2002; Brajša-Žganec, 2007). Also, sex differences are not pronounced in the first few years (Caplan et al., 1991, Keresteš, 2002), but they start to emerge in the preschool period (Raboteg Šarić, 1995; Žužul, Keresteš \& Vlahović - Štetić, 1990). Meta-analyses additionally confirm that boys are more aggressive in preschool age, while in the school age differences between them and girls are less pronounced (Vlahović-Štetić, 1994). However, the fact that kindergarten teachers often perceive only physical aggression and not some other types (verbal, passive, latent aggression) more typical for girls, should also be taken into account (Glavina \& Sindik, 2012).

Kindergarten is a child's first frontier for interactions with their peers and first teachers. It is a place where he learns competences in interpersonal relations and builds his first real relationships, which will serve him as a basis for the future (Ivon \& Sindik, 2011). The role of the kindergarten teacher in the child's socio-emotional development is immense, since prosocial skills can be adopted and can contribute to the suppression of aggressiveness. Teachers develop and encourage the social competencies in a child, because they know how to recognize, understand and respond to the complex challenges in education by collaborating with other experts and the child's family (Sindik \& Sindik, 2013; Glavina \& Sindik, 2012).

The first and main goal of this research was to construct estimation scales of social skills and undesirable behaviors of children and to test their metric properties. The second goal was to determine the age and gender differences in the dimensions of both newly constructed measuring instruments and the third one to determine the correlation between the dimensions of the undesirable behaviors of children and their prosocial skills.

\section{METHOD}

The kindergarten teachers (a total of 50) of 25 educational groups in kindergarten "Maslačak" in Zaprešić estimated the sample for this study. It consists of a total of 597 children ( 316 boys and 281 girls), actually all children who were regular attendees in certain kindergarten group, aged in range from one to seven, in the pedagogical year 2012/2013. 
We have used two scales (defined as new measuring instruments during the research): the Social Skills Scale and Scale for the Assessment of Undesirable Behaviors (Sindik Z., 2013, according to the Team of experts of the Kindergarten „Maslačak“, 2013), applied for the purpose of the annual report of the kindergarten, in May 2013. Kindergarten teachers (pairs of educators who work with the same group of children) assessed how many children from their educational group express a certain kind of behavior. Assessing was anonymous and with the permission of the parents, conducted as part of an annual analysis of the work of the kindergarten and the realization of its annual plan and program. The list of social skills, as well as the undesirable behaviors, was based on the practical experiences of the most common forms of this type of behavior in kindergarten.

In the statistical analysis of the data, the software package SPSS 11.0. was used. Latent dimensions of children's behavior characteristics were obtained by applying Principal Component Analysis (PCA) with Varimax rotation. For all the dimensions of both assessment scales, the reliability of type internal consistency (Cronbach's alpha) was calculated (Tables 1 and 2). For the Social skills assessment scale (71\% of total variance explained), both components showed high reliability and construct validity: the dimension of Active social skills ( 18 items, alpha $=0.97$; $43 \%$ variance explained) and the dimension of Passive social skills ( 7 items, alpha $=0.94 ; 28 \%$ variance explained). For two dimensions of Scale for the assessment of undesirable behaviors (in total $64 \%$ of variance explained), the high reliability and construct validity was revealed. For the dimension of Instrumental Undesirable behavior (6 items, alpha $=0.88 ; 22 \%$ of variance explained) and Reactive undesirable behavior ( 10 items, alpha $=0.94 ; 33 \%$ of variance explained), the reliability and construct validity were very high. For dimension Isolated undesirable behavior, reliability and validity were very low but still satisfactory ( 3 items, alpha $=0.52,9 \%$ of variance explained). All scores for latent dimensions of children's behavior (social skills and undesirable behaviors) are expressed in regression factor scores, in the analysis of differences and associations. Since a large part of the sample did not differ from the Gaussian curve, the analyses of the differences were performed using t-tests for independent samples, while in the correlation analyzes, we have used Pearson correlation coefficients.

\section{RESULTS}

The first two tables present the results of principal component analysis of both used scales (construct validity).

Table 1: Validity and reliability of the Social skills assessment scale (Principal Component Analysis, Varimax rotation)

\begin{tabular}{lccc}
\hline \multicolumn{1}{c}{ Child's social skills } & active social skills & passive social skills & $\begin{array}{c}\text { Communalities / } \\
\text { Extraction }\end{array}$ \\
\hline civilizational manners & $\mathbf{. 8 2 3}$ & .314 & .777 \\
protects physically weaker children & $\mathbf{. 8 1 7}$ & .342 & .784 \\
affirmed in the group & $\mathbf{. 7 8 9}$ & .392 & .777 \\
differentiate people & $\mathbf{. 7 8 3}$ & .450 & .816 \\
express needs and desires & $\mathbf{. 7 8 2}$ & .415 & .784 \\
looking into the eyes of interviewees & $\mathbf{. 7 7 3}$ & & .688 \\
expresses disagreement & $\mathbf{. 7 5 5}$ & .359 & .700 \\
take care of things & $\mathbf{. 7 4 8}$ & .328 & .668 \\
protects emotional children & $\mathbf{. 7 4 7}$ & .368 & .694 \\
takes care of itself & $\mathbf{. 7 3 9}$ & .395 & .702 \\
apologize when makes a mistake & $\mathbf{. 7 3 2}$ & .474 & .760 \\
asking for help when he/she need it & $\mathbf{. 7 0 5}$ & .464 & .712 \\
concerned about his/her appearance & $\mathbf{. 6 8 3}$ & .454 & .673 \\
controls emotions & $\mathbf{. 6 4 3}$ & .430 & .599 \\
defends weak children & $\mathbf{. 6 3 3}$ & .560 & .714
\end{tabular}




\begin{tabular}{|c|c|c|c|}
\hline helps to other children & .625 & .579 & .725 \\
\hline has a sense of good / evil & .598 & .595 & .711 \\
\hline waits for a desired toy & .398 & .797 & .793 \\
\hline accepts other children & .318 & .763 & .683 \\
\hline know to wait in a order & .367 & .760 & .713 \\
\hline accept a replacement toy & & .758 & .628 \\
\hline share toys with others & .438 & .711 & .698 \\
\hline collaborates with other children & .557 & .581 & .648 \\
\hline $\begin{array}{l}\text { like to include other children to play } \\
\text { together }\end{array}$ & .468 & .537 & .507 \\
\hline Variance explained (\%) & 42.733 & 27.904 & \\
\hline Eigenvalue & 10.256 & 6.697 & \\
\hline Reliability (Cronbach's alpha) & .974 & .941 & \\
\hline KMO measure of sample adequacy & \multicolumn{2}{|c|}{.968} & \\
\hline Bartlett's sphericity test $\left(\chi^{2}\right)$ & \multicolumn{2}{|c|}{$15537.630(\mathrm{p}<.001)$} & \\
\hline
\end{tabular}

Values of the KMO measure of sample adequacy and Bartlett's sphericity test $\left(\chi^{2}\right.$ significant at $\mathrm{p}<0.01$ ) showed that the matrix for set of variables called the Child's social skills is suitable for factorization. Application of Principal Component Analysis (PCA), using the Guttman-Kaiser criterion and Scree Plot showed that two-component solution is the most suitable for this set of variables. After Varimax rotation two principal components were obtained, which together interpret $70.6 \%$ of the total variance. The first component is defined by eighteen variables, dealing mostly with the various forms of active social skills of the child: it is named Active social skills and showed very high reliability (alpha $=0.974)$. The second component also defines eight three p.m. variables, dealing mostly with the various forms of passive social skills of the child: the so called passive social skills: this component also showed very high reliability $($ alpha $=0.941)$.

Table 2: Validity and Reliability of the Scale for the assessment of undesirable behaviors

(Principal Component Analysis, Varimax rotation)

\begin{tabular}{|c|c|c|c|c|}
\hline Undesirable child's behaviors & $\begin{array}{c}\text { reactive } \\
\text { undesirable } \\
\text { behaviors }\end{array}$ & $\begin{array}{c}\text { instrumental } \\
\text { undesirable } \\
\text { behaviors }\end{array}$ & $\begin{array}{c}\text { isolated undesirable } \\
\text { behaviors }\end{array}$ & $\begin{array}{l}\text { Communalities / } \\
\text { Extraction }\end{array}$ \\
\hline defying demands & .839 & & & .779 \\
\hline uncontrollable rage & .834 & & & .758 \\
\hline abducting children toys & .789 & .338 & & .764 \\
\hline destroying furniture and toys & .778 & .352 & & .756 \\
\hline impulsive & .772 & & & .679 \\
\hline physically conflict coping & .763 & .413 & & .754 \\
\hline crashes things & .743 & & & .661 \\
\hline disobedient, grudge match & .732 & .341 & & .664 \\
\hline weepy & .679 & & & .537 \\
\hline biting children & .503 & & & .316 \\
\hline excludes children, rejects & & .845 & & .784 \\
\hline dominates, ordering children & & .826 & & .747 \\
\hline eyelids children, mocking them & .324 & .817 & & .774 \\
\hline accuse children to their teacher & & .735 & & .627 \\
\hline intrusive & .390 & .627 & & .552 \\
\hline swear at children & .319 & .522 & & .386 \\
\hline isolates $\mathrm{him} / \mathrm{herself}$ & & & .799 & .726 \\
\hline shy & & & .709 & .525 \\
\hline isolated and rejected & & & .599 & .396 \\
\hline
\end{tabular}




$\begin{array}{lccc}\text { Variance explained (\%) } & 32.747 & 21.975 & 9.399 \\ \text { Eigenvalue } & 6.222 & 4.175 & 1.786 \\ \text { Reliability (Cronbach's } & .939 & .878 & .520 \\ \text { alpha) } & & .929 & \\ \text { KMO measure of sample } & & 7856.484(\mathrm{p}<.001) & \\ \text { adequacy } & & \\ \text { Bartlett's sphericity test }(\boldsymbol{\chi 2}) & & \end{array}$

Values of the KMO measure of sample adequacy and Bartlett's sphericity test $\left(\chi^{2}\right.$ significant at $\mathrm{p}<0.01$ ) showed that the matrix of the set of variables called Undesirable behavior of the child is suitable for factorization (Table 2). Application of Principal Component Analysis (PCA), using the Guttman-Kaiser criterion and Scree Plot showed that three-component solution is the most suitable for this set of variables. After Varimax rotation, it revealed three principal components, which together interpret $64.1 \%$ of the total variance. The first component is defined by thirteen variables, dealing mostly with the various reactive forms of undesirable behavior of the child: thus, it is named Reactive undesirable behavior and showed very high reliability $($ alpha $=0.939)$. The second component is defined by ten variables, dealing mostly with the various instrumental forms of undesirable behavior of the child: it is named Instrumental undesirable behavior and also showed relatively high reliability (alpha $=0.878$ ). The third component is defined by three variables, describing the specific form of undesirable behavior of children, and was named Isolated undesirable behavior. This component showed a very low but satisfactory reliability (alpha $=0.520$ ).

Table 3: Gender differences in dimensions of Social skills assessment scale and Scale for the assessment of undesirable behaviors

\begin{tabular}{|c|c|c|c|c|}
\hline Latent variable & Gender & Mean & Std. Dev. & t-test \\
\hline \multirow{2}{*}{ active social skills } & boys & -0.072 & 0.975 & \multirow{2}{*}{-1.760} \\
\hline & girls & 0.073 & 1.023 & \\
\hline \multirow{2}{*}{ pasive social skills } & boys & -0.097 & 1.013 & \multirow{2}{*}{$-2.476 *$} \\
\hline & girls & 0.106 & 0.979 & \\
\hline \multirow{2}{*}{ reactive undesirable behaviors } & boys & 0.194 & 1.097 & \multirow{2}{*}{$5.182 * *$} \\
\hline & girls & -0.217 & 0.830 & \\
\hline \multirow{2}{*}{ instrumental undesirable behaviors } & boys & -0.063 & 0.948 & \multirow{2}{*}{-1.623} \\
\hline & girls & 0.070 & 1.056 & \\
\hline \multirow{2}{*}{ isolated undesirable behaviors } & boys & 0.011 & 1.072 & \multirow{2}{*}{0.227} \\
\hline & girls & -0.007 & 0.916 & \\
\hline
\end{tabular}

Table 3 shows the gender differences in the dimensions of Social skills assessment scale and Scale for the assessment of undesirable behaviors. Significant differences were found in the realm of passive social skills, and in the dimension of reactive undesirable behavior. It turned out that girls more often showed behaviors that describe the dimension of passive social skills (they can wait a desired toy, welcomes others into the game, can wait for the order, accepts a replacement toy, share toy with others, collaborate in the game, like to be included in the play with others). Boys more often manifest behaviors that fall into the category of reactive undesirable behavior (they are more defiant, have frequent outbursts of rage, kidnap toys, destroy things, behave impulsive, hit, crash, they are more unruly, whimpering, biting). 
Table 4: Age differences in the dimensions of Social skills assessment scale and Scale for the assessment of undesirable behaviors

\begin{tabular}{|c|c|c|c|c|}
\hline Latent variable & Age group & Mean & Std. Dev. & t-test \\
\hline \multirow{2}{*}{ active social skills } & younger & -1.640 & 0.856 & \multirow{2}{*}{$-19.544 * *$} \\
\hline & older & 0.241 & 0.772 & \\
\hline \multirow{2}{*}{ pasive social skills } & younger & -0.133 & 1.325 & \multirow{2}{*}{-.973} \\
\hline & older & 0.020 & 0.937 & \\
\hline \multirow{2}{*}{ reactive undesirable behaviors } & younger & 0.836 & 1.359 & \multirow{2}{*}{$5.975 * *$} \\
\hline & older & -0.124 & 0.872 & \\
\hline \multirow{2}{*}{ instrumental undesirable behaviors } & younger & -0.557 & 0.936 & \multirow{2}{*}{$-5.341 * *$} \\
\hline & older & 0.087 & 0.987 & \\
\hline \multirow{2}{*}{ isolated undesirable behaviors } & younger & 0.032 & 0.948 & \multirow{2}{*}{.369} \\
\hline & older & -0.013 & 0.996 & \\
\hline
\end{tabular}

Table 4 shows the age-related differences in the dimensions of Social skills assessment scale or Scale for assessment of undesirable behaviors. Younger and older children are statistically significantly different in the levels of active social skills, reactive undesirable behavior, and instrumental undesirable behavior. Older children more often manifest behaviors from the category of active social skills and from category of instrumental undesirable behavior, while they rarely behave in the manner described with the dimension of reactive undesirable behavior.

Table 5: Correlations between the dimensions of Social skills assessment scale and Scale for the assessment of undesirable behaviors

\begin{tabular}{|c|c|c|c|}
\hline & $\begin{array}{l}\text { reactive undesirable } \\
\text { behaviors }\end{array}$ & $\begin{array}{l}\text { instrumental } \\
\text { undesirable behaviors }\end{array}$ & $\begin{array}{l}\text { isoated undesirable } \\
\text { behaviors }\end{array}$ \\
\hline active social skills & $-.330 * *$ & $.330 * *$ & $-.231 * *$ \\
\hline pasive social skills & $-.446 * *$ & $-.180 * *$ & $-.230 * *$ \\
\hline
\end{tabular}

Table 5 shows that the passive social skills are negatively and statistically significant, but very loosely associated with all three forms of undesirable behavior. On the other hand, active social skills are negatively and statistically significant but loosely associated with reactive undesirable behaviors, as well as with isolated undesirable behaviors, but positively, low and statistically significant with instrumental undesirable behaviors.

\section{DISCUSSION}

The main findings of our research are the following: we constructed two measuring scales with satisfying metric properties (reliability and construct validity); the first scale estimates prosocial (desirable) skills in preschool children (in different age groups) and the other estimates their undesirable behaviors, which are a common obstacle for a balanced psycho-physical development of a child. Two aspects of prosocial behavior types (represented in the two major questionnaire components) reflect the more passive social skills characteristic for younger children. Older children develop their social skills more actively, which results in greater diversity of their skills (Clark \& Ladd, 2000; Ulutas \& Aksoy, 2009), but also in a more frequent usage of prosocial behaviors connected with greater pleasure or social reward. They begin to understand their emotions much better (Brajša-Žganec \& Slunjski, 2007) and hence develop more complex (and even more creative) forms of social behavior.

Three aspects of undesirable behavior, represented in three major questionnaire components, reflect two behavior types (reactive undesirable and instrumental undesirable behavior), which can be interpreted similarly as two types of prosocial behavior. Namely, reactive undesirable behavior is characteristic for younger children. The third aspect represents 
undesirable behavior related to loneliness and isolation, which is also more typical for younger children (Eisenberg, 1988; Essau \& Conradt, 2006), but can also be a reflection of a specific personality trait, e.g. introversion. It is rather hard to distinguish whether a child's isolation in a specific group is a result of developmental problems (slower social or emotional development in certain aspects) or is it just a personality trait (Ivon \& Sindik, 2011).

Our results show that girls show passive social skills more often, which is in concordance with gender stereotypes that are being formed very early in life (Eisenberg \& Fabes, 1998; BrajšaŽganec \& Slunjski, 2007; Ivon \& Sindik, 2011). Results of our study also suggest that boys show reactive undesirable behavior more often, which can partly be attributed to the genetic or hormonal influences and partly to the socializing agents and socially "desirable" behavior for boys (Eisenberg, 1988; Essau \& Conradt, 2006). Younger children in general are also shown to have more frequent reactive undesirable behavior, which indicates that younger boys are a group which most often behaves reactively undesirable. It seems such behavior is most common for male gender and children of a younger age group (Eisenberg, 1988). Our results fit into this context, since they show that older children exhibit active social skills and instrumental undesirable behavior more frequently. As they develop, children widen the spectrum of their behavior forms, both desirable and undesirable ones. The correlation between these two opposite behavior types is low, although statistically significant. They do not exclude each other, or can be observed as opposites - they are behavior types which are combined differently depending on the gender, age and other variables of potential impact. Isolated undesirable behavior is negatively connected to passive and active prosocial skills and can be perceived as a result of a child's personality (most probably of introversion or of similar traits), but also of developmental problems.

The main value of this research is the construction of two new measuring instruments for the estimation of social skills and undesirable behaviors of preschool children in different age groups. Scale variables encompass most frequent types of both behaviors in kindergarten. We examined a representative sample of children from the total number of preschoolers in Zaprešić and the surrounding area, which is why our results can to a certain extent also be generalized to other Croatian urban areas. The limitation of our study is the lack of parental assessment and of separate assessments of two kindergarten teachers working in the same group, which would enhance the diagnostic value and objectivity of the research. In future research these scales could be applied to a representative sample of children in Croatian kindergartens and the practical use could be a construction of recommendations for the teachers. For example, the stimulation of socially desirable behavior in boys should include only instrumentally undesirable behavior, applied only in certain situations. When stimulating a child's social development, special accent should be put on the differentiation between the desirable and undesirable behavior and two social skill sets, both the active and the passive one, should be stimulated (Sindik \& Sindik, 2013).

\section{CONCLUSION}

We have constructed two measuring scales with satisfying metric properties (reliability and construct validity); the first scale estimates prosocial (desirable) skills in preschool children (with active and passive social skill components) and the other estimates their undesirable behaviors (with three components: reactive and instrumental undesirable behavior and undesirable behavior in relation to a child's isolation from the group). Our results indicate differences in gender; the passive social skills are more common for girls, while boys manifest reactive undesirable behavior more often. Older children use active social skills and instrumentally undesirable behavior more often and rarely show reactive undesirable behavior. The association between undesirable and prosocial (desirable) behavior is low, although statistically significant. 


\section{REFERENCES}

1.) Brajša-Žganec, A i Slunjski, E. (2007). Socioemocionalni razvoj u predškolskoj dobi: povezanost razumijevanja emocija i prosocijalnoga ponašanja. Društvena istraživanja, 16(3)(89): 477-496.

2.) Calvert, S. L., i Kotler, J. A. (2003). The Children's Television Act: Can media policy make a difference? Journal of Applied Developmental Psychology, 24: 375-380.

3.) Clark, K. E., i Ladd, G. W. (2000). Connectedness and autonomy support in parent-child relationships: Links to children's socioemotional orientation and peer relationships. Developmental Psychology, 36: 485-498.

4.) Cole, C. F., Arafat, C., Tidhar, C., Tafesh, W. Z., Fox, N. A., Killen, M., et al. (2003). The educational impact of Rechov Sumsum/Shara'a Simsim: A Sesame Street television series to promote respect and understanding among children living in Israel, the West Bank, and Gaza. International Journal of Behavioral Development, 27: 409-422.

5.) Eisenberg, N. (1988): The development of prosocial and aggressive behaviour. In M.H. Bornstein and M. E. Lamb (Eds.), Developmental psychology: An advanced textbook. New York: Lawrence Erlbaum Associates.

6.) Eisenberg, N., i Fabes, R. A. (1998). Prosocial development. In N. Eisenberg i W. Damon (Eds.), Handbook of Child Psychology, Vol. 4: Social, emotional and personality development (5th ed., pp. 701-778). New York: Wiley.

7.) Essau, C. A. i Conradt, J. (2006). Agresivnost u djece i mladeži : 22 slikovna prikaza, 11 tablica i 88 pitanja za vježbu. Jasterbarsko: Naklada Slap.

8.) Fehr, E. i Fischbacher, U. (2003). The nature of human altruism. Nature, 425: 785-791.

9.) Glavina, E. i Sindik, J. (2012). Utječe li dodatna edukacija odgojitelja o socijalnoj kompetenciji na učestalost prosocijalnog $\mathrm{i}$ agresivnog ponašanja djece predškolskog uzrasta? Zbornik instituta za pedagoška istraživanja, 44 (1): 180-195.

10.)Ivon, H. i Sindik, J. (2011). Razlike u prosocijalnom i agresivnom ponašanju djece predškolske dobi, ovisno o učestalosti djetetove interakcije s lutkom. Paediatr Croat, 55:27-34.

11.)Keresteš, G. (2002). Dječje agresivno i prosocijalno ponašanje u kontekstu rata. Jastrebarsko: Naklada Slap.

12.)Knafo, A. i Plomin, R. (2006). Prosocial Behavior From Early to Middle Childhood: Genetic and Environmental Influences on Stability and Change. Developmental Psychology, 42(5): 771-786.

13.)Krebs, D.L. (1970). Altruism - an examination of the concept and a review of the literature. Psychological Bulletin, 73(4):258 - 302.

14.)Lemery, K. S., i Goldsmith, H. H. (2002). Genetic and environmental influences on preschool sibling cooperation and conflict: Associations with difficult temperament and parenting style. Marriage and Family Review, 33: 77-99.

15.)Marangunić, N. (2002). Evaluacija upitnika sramežljivosti i asertivnosti USA-r: diplomski rad. Zagreb: Filozofski fakultet.

16.)McGue, M., Bouchard, T. J., Jr., Iacono, W. G. i Lykken, D. T. (1993). Behavioral genetics of cognitive ability: A life-span perspective. In R. Plomin i G. E. McClearn (Eds.), Nature, nurture, and psychology (pp. 59-76). Washington, DC: American Psychological Association.

17.)Ostrov, J, M., Gentile, D. A., Crick, N. R. (2006). Media Exposure, Aggression and Prosocial Behaviour During Early Childhood. A Longitudinal Study. Social Deveplopment, 15(4): 612-627.

18.)Plomin, R., DeFries, J. C., McClearn, G. E. i Z McGuffin, P. (2001). Behavioral Genetics (4th ed.). New York: Worth Publishers.

19.)Raboteg - Šarić, Z. (1995). Psihologija altruizma, Zagreb: Alineja.

20.)Shaffer, D.R. (1988). Social and personality development. Pacific Grove: Brooks/ Cole Publising Company. 
21.)Sindik, Z. i Sindik, J. (2013). Taksonomizacija nepoželjnih oblika ponašanja i socijalnih vještina kod predškolske djece. Zbornik Međimurskog veleučilišta u Čakovcu, 4 (2): 123 127.

22.) Team of experts of the Kindergarten „Maslačak“(2013). Annual report on the educational work. Zaprešić: Kindegarten Maslačak.

23.) Ulutas, I. i Aksoy, A. (2009). Learning with Play: How Play Activities Program Improve Pro-Social Behaviour of Six Year Old Children? Humanity \& Social Sciences Journal, 4(1): 39-44.

24.) Vlahović-Štetić, V. (1994). Priručnik za Skalu za procjenu agresivnog i prosocijalnog ponašanja kod djece (Pros/Ag). Jastrebarsko: Naklada Slap.

25.)Živković, Ž. (2006). Agresivnost kod djece. Đakovo: Tempo.

26.)Žužul, M. (1989). Agresivno ponašanje: psihologijska analiza. Zagreb: Radna zajednica Republičke konferencije Saveza socijalističke omladine Hrvatske.

27.)Žužul, M., Keresteš, G., Vlahović - Štetić, V. (1990). Skala za procjenu dječjeg agresivnog i prosocijalnog ponašanja. Primijenjena psihologija, 11:77-86.

\section{KONSTRUKCIJA SKALA PROCJENE NEPOŽELJNIH OBLIKA PONAŠANJA I SOCIJALNIH VJEŠTINA KOD PREDŠKOLSKE DJECE}

\section{SAŽETAK}

Nepoželjni oblici ponašanja su prepreka psihofizičkom razvoju djeteta koje ih pokazuje te ostaloj djeci u dječjem vrtiću, dok poželjne socijalne vještine doprinose konstruktivnom razrješavanju konflikata među djecom i prosocijalnim oblicima ponašanja. Ciljevi istraživanja bili su: konstruirati skale procjene socijalnih vještina te nepoželjnih oblika ponašanja djece, utvrditi dobne i rodne razlike u dimenzijama oba novokonstruirana mjerna instrumenta; utvrditi povezanosti između dimenzija nepoželjnih oblika ponašanja djece i njihovih prosocijalnih vještina. Odgojiteljice su procijenile listu obilježja za 597 dječaka i djevojčica predškolske dobi. Konstruirali smo dva mjerna instrumenta sa vrlo zadovoljavajućim metrijskim karakteristikama za procjenu prosocijalnih oblika ponašanja djece predškolske dobi. Pokazalo se da su kod djevojčica češće zastupljena ponašanja koja opisuju dimenziju pasivnih socijalnih vještina, dok dječaci značajno češće manifestiraju reaktivna nepoželjna ponašanja. Starija djeca značajno češće manifestiraju aktivne socijalne vještine, te instrumentalna nepoželjna ponašanja, dok rjeđe pokazuju reaktivna nepoželjna ponašanja. Povezanosti između nepoželjnih i prosocijalnih ponašanja većinom su niske, premda statistički značajne.

Ključne riječi: nepoželjna ponašanja, predškolska djeca, prosocijalne vještine 